\title{
Comparative characteristics of meat productivity of holstein and black-and-white breeds
}

\author{
Ivan Tuzov ${ }^{2}$, Nikolay Zabashta $^{1,2}$, Elena Kuleshova ${ }^{1}$, Valentin Golovan ${ }^{1}$, and Irina \\ Sinelshchikova ${ }^{1 *}$ \\ ${ }^{1}$ Department of Toxicology and Feed Quality, Krasnodar Research Centre for Animal Husbandry and \\ Veterinary Medicine, 4, Pervomayskaya Street, 350055, Krasnodar, Russia \\ ${ }^{2}$ Kuban State Agrarian University named after I.T. Trubilin, 13, Kalinina Street, 350044, Krasnodar, \\ Russia.
}

\begin{abstract}
It was assumed that the industry of beef cattle breeding being created in the Krasnodar Territory would meet the needs of the population in beef. Due to the fact that there are not enough beef cattle, dairy bulls are raised and fattened. Positive results are obtained in the case when, along with an increase in the number of the fattened livestock of animals, their intensive rearing and feeding is introduced. In our studies, with intensive rearing and fattening of the Holstein and Black-and-White bull calves, for the entire 14-month period of growing and fattening, average daily gains were obtained at the level of $1200 \mathrm{~g}$, and the gross weight gain was more than $500 \mathrm{~kg}$. According to the results of the slaughter of experimental bulls at the age of 14 months, we found that the Holstein bulls reliably exceeded the black-and-white bulls of the same age in all the studied parameters.
\end{abstract}

\section{Introduction}

Cattle breeders face the challenge of increasing beef production. It is possible to solve it in several ways, one of which is the breeding of beef cattle. Abroad, the problem of increasing beef production is solved through the development of specialized beef cattle breeding, using intensive meat breeds $[1,5,11]$.

The level of meat productivity of livestock and the quality of the beef produced depend on a number of factors. First of all, it is heredity, which manifests itself in one way or another, depending on the breed and individual characteristics of the animal. The most important factors influencing this indicator are environmental factors - feeding and keeping animals $[2,10,15]$.

Modern competitive technology of animal production makes special demands on the quality of animals, especially their resistance, strength of constitution, high reproductive and productive capacity. To obtain animals that meet these requirements, the conditions of directed rearing of young animals, especially during the dairy period, are of great importance.

* Corresponding author: ms.basana@list.ru 
These factors work closely together. It is extremely difficult to establish the degree of influence of a single factor on meat productivity. It is well known that heredity determines, and the conditions of the external environment ensure the development of the organism. It is believed that feeding accounts for $59 \%$, genetic factor $-24 \%$, and only $17 \%$ falls on certain technological methods $[9,12,13]$.

Beef contains all the nutrients vital for humans; when it is consumed, the processes of formation of its vital activity take place in the human body. This is due to the fact that beef contains all the components vital for people, which are digested and absorbed by $95 \%$ [8].

In our country, beef is mainly obtained from the use of dairy cattle. In recent years, in connection with the use of the Holstein breed of cattle to improve the breeds existing in Russia, the local cattle breeds are crossed with the Holstein cattle, which is one of the best dairy breeds in the world. In connection with the use of the Holstein breed, animals with new genotypes appeared, which have not yet been sufficiently studied in our conditions, especially in terms of meat productivity. The available data on the comparative study of the meat productivity of Holstein cattle is insufficient [6,7].

In this regard, an objective assessment of the meat productivity of fattened Holstein bulls for meat is relevant and of practical importance.

When creating the industry of beef cattle breeding in the Krasnodar Territory, it was supposed to meet the needs of the population in beef. Since in recent years the number of beef cattle remains insufficient, in some farms, bulls of dairy breeds are raised and fattened, while their intensive rearing is being introduced $[3,4,5,14]$.

\section{Materials and methods}

The purpose of our research was a comparative study of the meat productivity of Holstein and Black-and-White bulls, during life and after slaughter, in conditions of intensive growing and feeding technology. When carrying out research, we used generally accepted zootechnical methods and techniques. Using the method of pairs - analogues, two groups of animals, 30 animals each, were formed. Group I (experimental) included Holstein bulls of black-and-white colour, and Group II (control) included purebred Black-and-white bulls.

The study of growth and development was carried out in terms of live weight and the value of average daily weight gains, by individually weighing animals at different age periods, up to 14 months of age. Immediately after birth, optimal conditions for feeding and keeping were created for the animals, which were the same. During the first $1.5-2$ hours they were forced to drink colostrum, and they were placed in individual houses.

The farm uses a feeding technique called "rumen acceleration", which is due to the early use of grain concentrates (starter compound feed and corn) in the diet of calves. During the milk period, the calves drank 350 liters of whole milk, which was pasteurized and cooled before drinking. The rest of the feed they received in accordance with the rations adopted on the farm.

Feed consumption was taken into account every decade by the method of control feeding of animals. The quantity of the given feed and its eaten remains was weighed, and the actual eatability was determined by the difference. Based on the data obtained, the payment for feed products was established - an indicator that reflects the amount of products received from animals per unit of feed consumed by them.

\section{Results and discussion}

After 3 months of age, the bull calves were kept loosely, in groups. They received a feed mixture consisting of corn silage, haylage and alfalfa hay, and concentrated feed, which 
constituted $30 \%$ of the nutritional value of the diet until 12 months of age. In the period from 12 to 14 months, $25 \%$ of concentrated feed was included in the feed mixture. After 3 months of age, the experimental bull calves were fed with complete feed mixtures, the animals had free access to the feed mixture and ate the amount of feed required for them.

To characterize the protein metabolism in the body of animals of the experimental groups at the age of 2 months, blood was taken from the jugular vein and some indicators characterizing the exchange of nitrogen and minerals were determined (Table 1).

Table 1. Biochemical parameters of blood $(n=3), 0$

\begin{tabular}{|c|c|c|}
\hline \multirow{2}{*}{ Items } & \multicolumn{2}{|c|}{ Breed } \\
\hline & Black and White & Holstein \\
\hline Total Protein. g \% & 6.85 & 6.91 \\
\hline Albumins. \% & 42.39 & 42.63 \\
\hline Globulins. \% & & \\
\hline$£$ & 14.79 & 14.81 \\
\hline$\beta$ & 14.13 & 14.27 \\
\hline$\gamma$ & 28.60 & 29.08 \\
\hline in total & 57.52 & 58.16 \\
\hline Protein ratio & 0.74 & 0.73 \\
\hline Inorganic phosphorus. g \% & 6.51 & 6.61 \\
\hline Calcium. g \% & 11.28 & 11.29 \\
\hline
\end{tabular}

Studies have shown that the amount of total protein in the blood of Holstein calves was $0.8 \%$ higher compared to black-and-white calves. The increase in total protein in the blood serum of calves in the Holstein breed can be explained by the fact that the animals grew better, as can be judged by the increase in live weight. Changes in live weight and average daily gains are the main indicators that characterize the nature of nutrition and the state of health of experimental animals, which makes it possible to judge the impact of the diet as a whole.

At the age of 14 months, the live weight of Holstein bulls was $560 \mathrm{~kg}$, and that of analogues of the black-and-white breed was $539 \mathrm{~kg}$. The dynamics of live weight is shown in Fig. 1

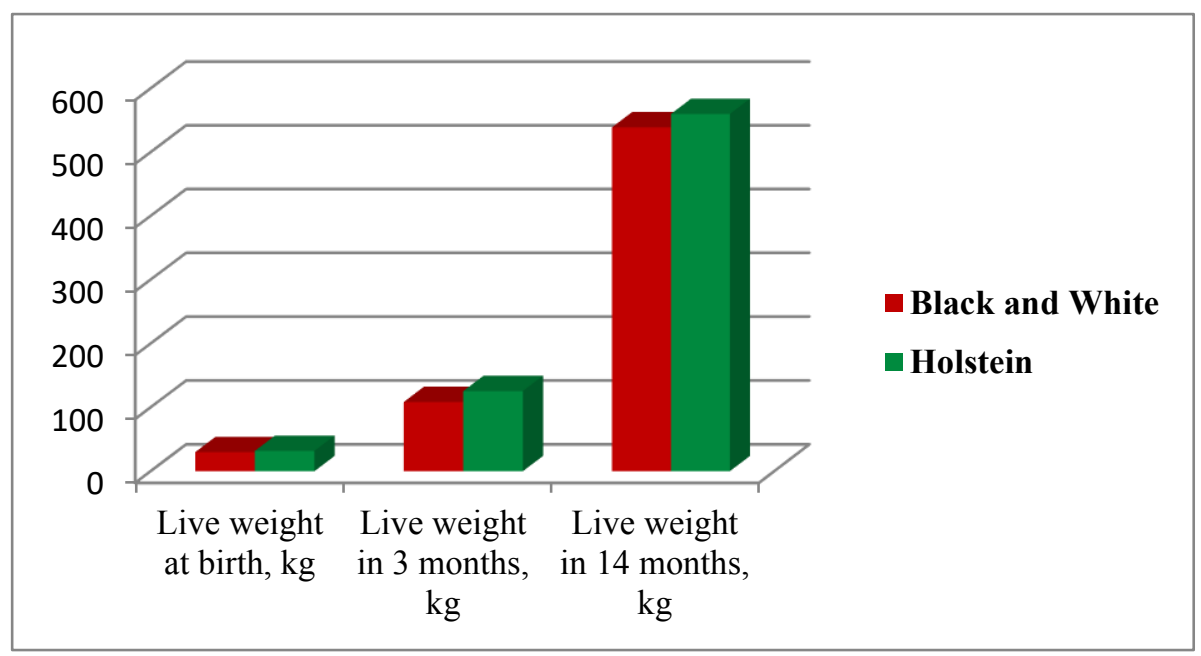

Fig. 1 Dynamics of live weight of gobies, kg.

With age, the live weight of bull calves does not increase to the same extent. Holstein gobies with age are more and more superior in live weight to the analogues of the black- 
and-white breed. At birth, for example, Holstein bulls outperform their peers by only 2.3 $\mathrm{kg}$, at 6 months this gap is $20.6 \mathrm{~kg}$, and at 14 months $-21.1 \mathrm{~kg}$.

During the entire period of growing and fattening Holstein and Black-and-White bulls, Holstein bulls grew more intensively. Their average daily weight gain for 14 months of growing was 1238 grams and 43.3 grams higher than that of their peers of the Black-andWhite breed. The absolute increase in live weight over the period of the experiment in young black-and-white breeds was 509.2, which is lower than the Holstein peers by 19.5 $\mathrm{kg}$. At the same time, feed costs for Holstein animals amounted to $5.2 \mathrm{k}$ units, which is $10.34 \%$ lower, which is explained by a higher growth rate.

Table 2. Payment for feed when raising young farm animals.

\begin{tabular}{|l|l|l|}
\hline \multirow{2}{*}{ Items } & Breed \\
\cline { 2 - 3 } & Black and White & Black and White \\
\hline Live weight at setting. $\mathrm{kg}$ & $29.8 \pm 2.2$ & $31.3 \pm 0.83$ \\
\hline $\begin{array}{l}\text { Live weight at the end of the experiment. } \\
\mathrm{kg}\end{array}$ & $539.1 \pm 2.2$ & $560 \pm 2.8$ \\
\hline Absolute gain. kg & $509.2 \pm 3.1$ & $528.7 \pm 2.5$ \\
\hline Average daily growth. g & 1195 & 1238 \\
\hline $\begin{array}{l}\text { Feed unit costs per 1 kg of live weight } \\
\text { gain }\end{array}$ & 5.8 & 5.2 \\
\hline
\end{tabular}

To study the characteristics of the formation of meat productivity in experimental animals, three bulls were selected from each group for control slaughter, which was carried out at the age of 14 months. The results of the control slaughter are shown in the table.

Table 3. Results of slaughter of bulls at the age of 14 months $M \pm m(n=3)$.

\begin{tabular}{|l|l|l|l|}
\hline \multirow{2}{*}{ Items } & \multicolumn{3}{|c|}{ Group } \\
\cline { 2 - 4 } & I & II & td \\
\hline Pre-slaughter weight, $\mathrm{kg}$ & $543.2 \pm 6.9$ & $523.4 \pm 7.1$ & 2.0 \\
\hline Carcass weight, $\mathrm{kg}$ & $285.5 \pm 3.1$ & $274.4 \pm 3.5$ & 2.4 \\
\hline Internal fat weight, $\mathrm{kg}$ & $8.9 \pm 0.6$ & $9.9 \pm 0.8$ & 1.0 \\
\hline Slaughter weight, $\mathrm{kg}$ & $294.4 \pm 2.7$ & $284.2 \pm 3.3$ & 2.4 \\
\hline Slaughter yield, \% & 54.2 & 54.3 & \\
\hline
\end{tabular}

Despite the same feeding and keeping conditions, the heaviest carcasses were obtained after the slaughter of Holstein bulls.

In the experimental bulls of the first group, the pre-slaughter weight after starvation was $543.2 \mathrm{~kg}$, which is $19.8 \mathrm{~kg}$, or $3.8 \%$ more, compared to the analogues of the second group, in which this indicator was $523.4 \mathrm{~kg}$. The established differences in the pre-slaughter weight turned out to be significant, $\mathrm{td}=2$, at $\mathrm{P}>0.95$ in favor of Holstein bulls from the first group.

The heaviest carcass weight was in the bulls of the I group $-285.5 \mathrm{~kg}$, in the peers of the II group, it was $274.4 \mathrm{~kg}$. Thus, Holstein bulls in carcass weight exceeded their peers of the Black-and-White breed by $11.1 \mathrm{~kg}$, or $4.0 \%$. The established differences are statistically highly significant, with $\mathrm{P}>0.95$.

The formation of adipose tissue in the body of animals is uneven. In the event that optimal conditions for feeding and keeping are created for the animal during their fattening period, then first of all, adipose tissue begins to be deposited on the internal organs, secondly, it is deposited in the animal's body between individual muscles and, last of all, under the skin. Last but not least, by the end of the fattening of the animal, fat begins to be 
deposited in muscle tissue. The deposition of fat in muscle tissue is characteristic of beef cattle.

In our studies, experimental bulls differed insignificantly in the content of internal fat, the amount of internal fat in the carcasses of bulls in the control group was $8.9 \mathrm{~kg}$, in peers of the control group its content was $1.0 \mathrm{~kg}$ more and amounted to $9.9 \mathrm{~kg}$, the established difference was not significant, $\mathrm{P}<0.95$.

The slaughter weight shows approximately the same pattern as when comparing the carcass weight.

The slaughter weight of the bulls of the experimental group was $294.4 \mathrm{~kg}$, according to this indicator, they exceeded their counterparts of the Black-and-White breed by $10.2 \mathrm{~kg}$, or $3.6 \%$. The established differences in slaughter weight between the animals of the experimental groups under study are not reliable, $\mathrm{td}=2.4$, with $\mathrm{P}>0.95$.

The slaughter yield in the experimental bulls of both groups was quite high for young animals of the dairy direction of productivity and amounted to $54.2-54.3 \%$, and this indicator was higher in the Holstein bulls.

Based on the data from the slaughter of experimental bull calves at the age of 14 months, we conclude that with intensive rearing and fattening of Holstein and Black-andWhite bulls, subject to the zoohygienic and technological requirements, Holstein bulls grew more intensively than their counterparts of Black-and-white breed. By all indicators studied after slaughter, the Holstein bulls were significantly superior to their peers of the Blackand-White breed. The slaughter yield was quite high and amounted to 54.2 and $54.3 \%$ in the experimental bulls of the first and second groups, respectively. An objective judgment about the quality of the meat of experimental steers is given by the study of the chemical composition of the average sample of meat and the longest back muscle. It should be noted that in $1 \mathrm{~kg}$ of the average sample of meat of black-and-white bull calves, the moisture content was slightly less by $0.5 \%$; protein-by $0.5 \%$; more fat-by $0.39 \%$ in comparison with animals of the Holstein breed. According to the data obtained, the meat of steers of the presented groups met the requirements of GOST 31798-2012. The need to assess the safety of meat raw materials for the presence of pollutants in them is noted by many authors [5]. This is due to the need to provide the population with environmentally safe products, including beef, where the content of toxic substances should not exceed the maximum permissible concentrations (MPC), which is of great social importance [4,5].

Table 4. Content of toxic elements in the longest muscle $\mathrm{mg} / \mathrm{kg}(\mathrm{n}=3)$.

\begin{tabular}{|c|c|c|c|}
\hline \multirow{2}{*}{ Items } & \multirow{2}{*}{ MPC } & \multicolumn{2}{|c|}{ Breed } \\
\cline { 3 - 4 } cadmium & no $>0.03$ & $0.001 \pm 0.001$ & $0.003 \pm 0.010$ \\
\hline mercury & no $>0.01$ & no $<0.005^{*}$ & no $<0.005^{*}$ \\
\hline lead & no $>0.1$ & $0.02 \pm 0.01$ & $0.05 \pm 0.01$ \\
\hline arsenic & no $>0.1$ & no $<0.0025^{*}$ & no $<0.0025^{*}$ \\
\hline
\end{tabular}

The analysis of the obtained data confirms that the concentration of heavy metals in the muscle tissue of young animals does not exceed the maximum permissible concentration.

\section{Conclusion}

The results of the conducted scientific and economic experience allow us to draw the following conclusions: 
- the conducted research has established that in terms of live weight, gross, average daily gains, the Holstein gobies are superior to their peers of the black-and-white breed;

- gobies of the Holstein breed had a higher pre-slaughter weight, it was $543.2 \mathrm{~kg}$, while the analogs of the black-and-white breed had this indicator of $523.4 \mathrm{~kg}$.;

- the slaughter yield of the Holstein gobies was $54.2 \%$, and the black-and - white$54.3 \%$.

The use of Holstein steers in the production of beef is more cost-effective in comparison with the analogues of the black-and-white breed.

\section{References}

1. M. Pospiech, T. Zikmund, Z. Javůrkova, J. Kaiser, B. Tremlova, Food Analytical Methods, 12(3), 652-657 (2019) doi : 10.1007/s12161-018-1394-8

2. K. Wieja, P. Kiełczyński, S. Ptasznik, 348 (1), 76-83 (2020)

3. N.N. Zabashta, E.N. Golovko, I.A. Sinelshchikova, A.N. Androsova, E3S Web of Conferences, 210, 4 December's (2020) doi : 10.1051/e3sconf/202021003005

4. N.N. Zabashta, E.N. Golovko, I.A. Sinelshchikova, A.N. Androsova, E3S Web of Conferences 210, 4 December's (2020) doi : 10.1051/e3sconf/202021006004

5. N. Zabashta, E. Golovko, I. Sinelshchikova, A. Visokopoyasnaya, E3S Web of Conferences XIII International Scientific and Practical Conference "State and Prospects for the Development of Agribusiness - INTERAGROMASH, 175, 29 June (2020) doi : 10.1051/e3sconf/202017508008

6. V.G. Litovchenko, M.R. Markovic, Ecological agriculture and sustainable development Research Development Center-FBEE, Belgrade, Serbia Proceedings Filodiritto, Bologna, Italy, 381 (2019)

7. V.M. Abramov, V.A. Drabenko, et al., Conference: XVI International Baltic Sea Day Environmental Forum, 18-20, March (2015) doi : 10.13140/rg.2.1.2420.4320

8. B. Blagojevic, T. Nesbakken, L. Alban, et al., Food Control, 124, 12 January (2021)

9. C.S. Takiya, C.M. Ylioja, A. Bennett, et al., Frontiers in Sustainable Food Systems, 3, 19, December 114 (2019)

10. V.I. Fisinin, M.I. Selionova, L.A. Shinkarenko, N.G. Shcherbakova, L.V. Kononova Sel'skokhozyaistvennaya Biologiya, 52 (4), 739-748 (2017)

11. S. Bernardi, M. Vega, P. Marini, Asociacion Peruana de Reprouduccion Animal, 9(2), 92-94 (2019)

12. N. Widyas, N. Mahfudhoh, S., Prastowo International Conference on Science and Applied Science, 2202, 020076 (2019) doi :10.1063/1.5141689

13. N. Morozov, A. Rasskazov, IOP Conference Series: Earth and Environmental Science, 403, 19 December 012117 (2019)

14. F. Peles, P. Sipos, Z. Győri, et al., Frontiers in Microbiology, 10, 11 December 2861 (2019)

15. E.E. Connor, J.L. Hutchison, C.P. Van Tassell, J.B. Cole, Journal of Dairy Science, 102(7), 6131-6143 (2019) 